\title{
Gestão Social e Governança Pública: aproximações e (DE)LIMITAÇÕES TEÓRICO-CONCEITUAIS
}

\author{
Social Management and Public Governance: theoretical and \\ conceptual approaches and delimitations
}

\begin{abstract}
Valderí de Castro Alcântara
Doutorando do Programa de Pós-Graduação em Administração da Universidade Federal de Lavras (DAE/UFLA) e Pesquisador do Núcleo de Estudos em Administração Pública e Gestão Social (NEAPEGS/UFLA). Lavras, MG, Brasil. E-mail: valderi.alcantara@ posgrad.ufla.br
\end{abstract}

José Roberto Pereira

Doutor em Sociologia pela Universidade de Brasília. Professor Associado e Pró-Reitor de Cultura e Extensão da Universidade Federal de Lavras. Lavras, MG, Brasil. E-mail: jrobertopereira2013@gmail.com

\section{Érica Aline Ferreira Silva}

Mestranda do Programa de Pós-Graduação em Administração da Universidade Federal de Lavras (DAE/UFLA) e Pesquisadora do Núcleo de Estudos em Administração Pública e Gestão Social (NEAPEGS/UFLA). Lavras, MG, Brasil. E-mail: erica_alline@hotmail.com

\section{Resumo}

Neste ensaio serão abordadas as aproximações e as delimitações teórico-conceituais entre gestão social e governança pública. Para tanto, busca-se na redução sociológica de Guerreiro Ramos a possibilidade de articulações teóricas sem deformar conceitos de matrizes epistemológicas distintas. Foram operacionalizadas as análises por meio de cinco categorias: racionalidade e lógica de ação; protagonismo e interesse; genealogia e epistemologia; dinâmica e desafios do campo científico; e relações entre Estado, mercado e sociedade. Por um lado, os conceitos aproximam-se pela orientação das ações por meio do interesse público e dos princípios e práticas da transparência, autonomia, pluralismo, participação e bem comum. Por outro, se distanciam no que diz respeito ao protagonismo das ações e à sua orientação específica: na governança pública, a orientação é o interesse público estatal e o protagonismo é do Estado; na gestão social, a orientação é o interesse público não estatal e o protagonismo, da sociedade.

Palavras-chave: Gestão Social. Governança Pública. Redução Sociológica. Interesse Público.

\section{Abstract}

We address in this paper the theoretical and conceptual approaches and delimitations between social management and public governance. Therefore, we sought on the sociological reduction formulated by Guerreiro Ramos the possibility of theoretical articulations without deforming the concepts of distinct epistemological matrices. We operationalize analyzes through five categories: rationality and logic of action; protagonism and interest; genealogy and epistemology; dynamics and challenges of the scientific field and relations between state, market and civil society. On the one hand, the concepts are similar to the orientation of the shares through the public interest and the principles and practices of transparency, autonomy, pluralism, participation and the common good. However are distant with respect to the protagonism of the shares and its specific orientation: in the public governance the orientation is the state public interest and the State is protagonist; in social management the orientation is public non-state interest and the society is protagonist.

Keywords: Social Management. Public Governance. Sociological Reduction. Public Interest. 


\section{INTRODUÇÃO}

Para a realização de pesquisas é importante haver delimitação de um campo de conhecimento científico. É nesse campo, com suas ontologias, epistemologias e metodologias, que o pesquisador irá construir conhecimento e se relacionar com os sujeitos e objetos de estudo. O pesquisador precisa conhecer os fundamentos epistemológicos da produção do conhecimento em seu paradigma. Logo, é importante evitar a utilização de um conceito sem conhecer os pressupostos da dimensão epistemológica na qual ele se originou (FARIA, 2012).

Posto isso, é sensato colocar que a delimitação do campo de estudo é uma condição essencial para o desenvolvimento de uma pesquisa. Concorda-se que não é apenas de debates epistemológicos (BARBOSA et al., 2013) e teóricos que vivem as pesquisas em Administração e Administração Pública, no entanto, no que tange à delimitação da Gestão Social, essa discussão é fundamental $e$ ainda precisa ser ampliada, até mesmo o diálogo com outras disciplinas do conhecimento. Como acrescentam lizuka, Gonçalves-Dias e Aguerre (2011, p. 749) "[...] na medida em que a gestão social se encontra em debate, os esforços no sentido de aperfeiçoamento da sua compreensão teórica e empírica são legítimos e relevantes".

Destaca-se que a gestão social tem buscado consolidação conceitual/teórica e procura constituir o seu primeiro paradigma, mesmo ainda sendo pré-paradigmática e in progress (CANÇADO, 2011; ARAÚJO, 2012). Nesse caminho, segundo Cançado (2011), a gestão social busca se consolidar de forma adversa a prescrição. No entanto, alguma delimitação se faz necessária, afinal, "[...] a polissemia pode esvaziar de conteúdo o significado" (CANÇADO, 2013, p. 193). Isso é importante: "[...] se não existe certo ou errado, só pontos de vistas diferentes, a ciência organizacional contranormal [e a gestão social se apresenta como não positivista] mina seus próprios fundamentos." (MARSDEN; TOWNLEY, 2001, p. 49).

Para Peres Jr., Pereira e Oliveira (2013, p. 21),

[...] a Gestão Social encontra-se em uma fase de busca de sua consolidação conceitual e teórica, absorvendo conceitos interdisciplinares de diversas perspectivas teóricas, destacando-se, sobretudo, a abordagem da teoria crítica frankfurtiana [principalmente de Habermas].
Destaca-se também as contribuições da abordagem da teoria da estruturação de Giddens, do sociólogo Boaventura de Sousa Santos e de autores latino-americanos, especialmente, Guerreiro Ramos e Bernardo Kliksberg, dentre outros. Dessa forma, diversas temáticas são abordadas em relação à gestão social: esfera pública, esfera social, economia solidária, territórios, cidadania, desenvolvimento territorial, políticas públicas, deliberação, racionalidade, participação e outras que abrangem áreas de estudos da Administração, Administração Pública, Serviço Social, Ciência Política e Sociologia. Contudo, uma análise preliminar indica como lacuna os debates na direção do conceito de governança pública.

A governança pública está sendo discutida mais recentemente no Brasil como um modelo pautado na cooperação entre Estado, mercado e sociedade civil em prol de objetivos comuns, apresentando, nesse cenário, proximidades com o conceito de gestão social. Ademais, são encontrados na literatura alguns trabalhos que utilizam os conceitos de gestão social e governança conjuntamente, a saber: "gestão social e governança territorial" (CANÇADO; TAVARES; DALLABRIDA, 2013) e "gestão social e governança urbana" (SOUSA et al., 2014). Todavia, uma discussão mais aprofundada das aproximações e interfaces se faz importante pelo crescimento da literatura sobre gestão social e governança pública, juntamente com a importância destes conceitos para a democracia brasileira.

Diante do exposto, pretende-se abordar neste ensaio teórico as aproximações e as delimitações teórico-conceituais entre gestão social e governança pública. Para tanto, busca-se na redução sociológica de Guerreiro Ramos (1965) a possibilidade de articulações teórico-conceituais sem deformar conceitos com matrizes epistemológicas distintas, e, nesse sentido, é fundamental apresentar o contexto em que o conceito foi construído (RAMOS, 1965; 1981; FARIA, 2009; 2012). Assim, a redução sociológica possibilita um filtro crítico quando se pretende transpor, aproximar ou delimitar conceitos (BERGUE; KLERING, 2010; BERGUE, 2011). Destaca-se que o artigo contribui para ambos os campos de estudos, gestão social $e$ governança pública, apresentando seus elementos comuns e divergentes e algumas imprecisões conceituais, no sentido de despertar/direcionar pesquisas de campo que explorem esse diálogo. É importante consi- 
derar que este artigo parte do campo da gestão social (especificamente da tradição iniciada pelos textos do professor Fernando G. Tenório) na busca por incluir o outro na governança pública (a partir de uma crítica desta). Finalmente, são operacionalizadas as análises por meio de cinco categorias: racionalidade e lógica de ação; protagonismo e interesse; genealogia e epistemologia; dinâmica e desafios do campo científico e relações entre Estado, mercado e sociedade.

Este artigo é desenvolvido na forma de ensaio $e$ está estruturado em seis partes. A seguir será apresentada a redução sociológica. Nas duas próximas seções apresenta-se um panorama da gestão social (seção 3) e da governança pública (seção 4) para posteriormente discutir as aproximações e delimitações teóricas e conceituais (seção 5). Nas considerações finais ressalta-se a síntese do debate, as limitações e uma breve agenda de pesquisas.

\section{A Redução Sociológica de Guerreiro RAMOS}

A redução sociológica é importante quando se pretende fazer reflexões acerca da transposição de tecnologias ou até mesmo de conceitos (FARIA, 2009; BERGUE, 2011). Ela "[...] consiste na eliminação de tudo aquilo que, pelo seu caráter acessório e secundário, perturba o esforço de compreensão e a obtenção do essencial de um dado [...] seja praticada no domínio teórico, seja no domínio das operações empíricas." (RAMOS, 1965, p. 81-82).

A redução permite considerar que aquilo que vem do exterior não seja invalidado - podendo ser criticamente incorporado (BERGUE, 2011): "[...] é um método para habilitar o estudioso a praticar a transposição de conhecimentos e de experiências de uma perspectiva estrangeira para outra, nacional." (FARIA, 2009, p. 426; grifo do autor). Concomitantemente, o processo de redução deve ser operacionalizado de forma radical para que se alcancem os seus pressupostos nucleares (RAMOS, 1965): “[...] a redução sociológica, em sentido amplo, implica a busca da essência de um determinado elemento, assim entendida como o seu conteúdo nuclear." (BERGUE; KLERING, 2010, p. 141).
A redução sociológica, como se mencionou, é muito relevante nos debates sobre transposição de conceitos e teorias. Na Administração ele é fundamental, afinal, segundo Bertero, Caldas e Wood Jr, (1999), nossa produção científica sofre, dentre outras coisas, de um mimetismo mal informado. Antes disso, Guerreiro Ramos (1981, p. 81) já se referia na década de 1980 à colocação inapropriada de conceitos que "[...] impregna a literatura contemporânea sobre tópicos e problemas organizacionais". Em relação à Administração Pública, o mesmo ocorreu com os mimetismos, os modismos e a transposição de técnicas gerenciais do setor privado (e da sua lógica) para o setor público (ANDREWS; KOUZIMIN, 1998; POLLITT, 2000; TORRES, 2004; PAES DE PAULA, 2005a; 2005b; DIEFENBACH, 2009).

O caso brasileiro revela esses aspectos na emergência da Administração Pública Gerencial, produto de uma onda de reformas que se originou principalmente no Reino Unido e nos Estados Unidos (New Public Management). Essas reformas se mostraram como um processo de transferências de conhecimentos, práticas e modelos gerenciais do setor privado para o setor público (PAES DE PAULA, 2005a). No entanto, isso ocorreu sem a redução necessária em decorrência das lógicas, de interesses e de necessidades distintas entre os setores, bem como o fato de que as reformas foram implementadas mimeticamente às realizadas por outros países (POLLITT, 2000; PAES DE PAULA, 2005a). Esses processos ainda estão em implementação e em discussão em diversos níveis, do nacional ao municipal.

Adiante, com base em Ramos (1981) é possível considerar que o norte da gestão pública não deve ser o mesmo da privada, pois são sistemas sociais que possuem especificidades: caminhar no sentido da eficiência e do desempenho não reflete, necessariamente, em processos de democratização (PAES DE PAULA, 2005a). Por isso, Paes de Paula (2005a) apresenta o modelo Societal. Para a autora, esse modelo busca ressignificar as relações entre Estado e sociedade que passam a ser pensadas de forma a englobar a participação e a deliberação, assim, "[...] o paradigma adotado é o da gestão social" (PAES DE PAULA, 2010, p. 493). Referenciando o trabalho de Tenório (1998), a autora afirma que a gestão social "[...] enfatiza a elaboração de experiências de gestão focalizadas nas demandas do público-alvo, incluindo questões culturais e participativas" (PAES DE PAULA, 2005b, p. 41). Finalmente, 
posto isso, a lógica da gestão social difere da lógica do gerencialismo e, assim, busca a gestão como um processo dialógico e que paute sua construção no contexto nacional.

A par disso, destaca-se que as discussões no campo da Administração Pública (principalmente nos EUA e Europa) caminham na direção da Governança Pública que busca superar os limites da reforma gerencial (KISSLER; HEIDEMANN, 2006). Tais discussões estão presentes no Brasil desde a década de 1990 (DINIZ, 1998), mas ganharam a pauta nacional mais recentemente (SECCHI, 2009; RAQUEL; BELLEN, 2012). Inicialmente, a redução sociológica nos leva a considerar que gestão social e governança pública são conceitos que emergem de locus e debates conceituais distintos, mas que podem ser aproximados e delimitados, se o processo for realizado com o devido filtro crítico.

\section{Abordagens da Gestão Social no BRASIL}

A gestão social se apresenta como um campo de conhecimentos e práticas emergentes em gestão que busca processos dialógicos e emancipadores (ARAÚJO; FRANÇA FILHO; BOULLOSA, 2014). A sua produção nacional se apresenta em um período de crescimento e fortalecimento como campo do saber científico, pois, "[...] existe um movimento de pesquisadores no país que desde a década de 1990 vem se debruçando sobre esta temática." (CANÇADO; TENÓRIO; PEREIRA, 2011, p. 682).

No que tange à origem do termo, Cançado (2011, p. 103) revela que não existe consenso e que "[...] a principal pista vem dos textos do professor Tenório, que, desde 1990, está à frente do Programa de Estudos em Gestão Social". Nessa direção, para Iizuka, Gonçalves-Dias e Aguerre (2011, p. 750), "[...] os debates sobre gestão social no Brasil têm o seu início a partir dos primeiros anos da década de 1990 e naquele momento era um conceito restrito às organizações do chamado terceiro setor". Hoje, as discussões se ampliaram para o âmbito público e das empresas privadas, assim como das organizações da sociedade civil.

O principal conceito foi apresentado por Tenório (1998), principalmente, com base na Teoria Crítica e na Teoria da Ação Comunicativa de Habermas, e, assim, se fundamenta na racionalidade comunicativa. Desse modo, a gestão social contrapõe-se à gestão estratégica pautando-se pelo gerenciamento mais participativo $e$ dialógico na busca do entendimento. Posteriormente, Tenório (2008, p. 39) define a gestão social como um "[...] processo gerencial dialógico onde a autoridade decisória é compartilhada entre os participantes da ação". Para o autor, a chave dessa possibilidade reside na democratização estabelecida por meio da intersubjetividade - na busca de um acordo alcançado comunicativamente no qual a sociedade civil deixa de ser coadjuvante (TENÓRIO, 2005; 2008; 2012). Nesse processo, as decisões são tomadas e legitimadas por meio das ações dos cidadãos, que devem ser orientadas pela inclusão, pluralismo, igualdade, autonomia e bem comum (TENÓRIO et al., 2010).

Nesse mesmo escopo, destaca-se o trabalho de Cançado, Pereira e Tenório (2013, p. 17), que define a gestão social como um "[...] campo do conhecimento científico, de uma ação gerencial dialógica própria da sociedade, do interesse público não estatal e voltado para o bem comum". Por conseguinte, a gestão social possui como finalidade a emancipação. Esses autores nos convidam para o aprofundamento das categorias teóricas como também para a análise e a elaboração de metodologias para a gestão social. Atento a isso, esse ensaio visa contribuir no âmbito teórico buscando aproximações e delimitações com a governança pública.

A perspectiva apresentada não é a única do campo, isto é, "[...] a Gestão Social não é uma narrativa uniforme e homogênea" (JUSTEN; MORETTO NETO; GARRIDO, 2014, p. 240). Maia (2005, p. 14) destaca também diversas perspectivas da gestão social considerando que "[...] os locos, espaços ou campos de viabilização da gestão social, são especialmente identificados nas organizações, tanto do Estado, quanto do mercado e da sociedade civil". Ampliando isso, Peres Jr. e Pereira (2014) encontraram na produção acadêmica quatro abordagens centrais: abordagem crítica frankfurteana (acima parcialmente referenciada), abordagem da gestão do desenvolvimento social interorganizacional, abordagem puquiana e abordagem da administração pública societal.

Destaca-se que as discussões apresentadas anteriormente (TENÓRIO, 2005; 2008; 2012; TENÓRIO et al., 2010; CANÇADO; TENÓRIO; PEREIRA, 2011; 
CANÇADO, 2011; CANÇADO; PEREIRA; TENÓRIO, 2013) são referentes à abordagem crítica frankfurteana e revelam algumas de suas principais características, as quais, podem ser condensadas no seguinte conceito: "[...] processo dialético de organização social próprio da esfera pública, fundado no interesse bem compreendido, e que tem por finalidade a emancipação" (CANÇADO; PEREIRA; TENÓRIO, 2013, p. 187). Acrescenta-se que é principalmente dessa abordagem que se fazem as aproximações.

Inseridos também na primeira abordagem citada (PERES JR.; PEREIRA, 2014), os trabalhos de França Filho $(2003 ; 2008)$ relacionam o espaço da gestão social com a sociedade civil. Na corrente gestão do desenvolvimento social interorganizacional destacam-se os trabalhos de Fischer (2004; 2012), Fischer, Melo e Codes (2004) e Fischer (2012). Nessa linha, desenvolvem-se pesquisas relacionadas ao desenvolvimento territorial mediante o conceito de interorganizações. Em destaque, Fischer et al. (2006) colocam que a gestão social pode ser praticada no âmbito público e privado - Maia (2005) afirma que os trabalhos de Fischer focam na ideia de gerir processos de desenvolvimento social. A abordagem que se pauta no conceito de administração pública societal referenciam os textos de Paes de Paula (2005a; 2005b). Aqui, se destacam os estudos sobre as experiências de participação e deliberação focadas nas demandas dos cidadãos. De forma ampla, o modelo societal advoga que o cidadão é participante ativo e não apenas um cliente do processo.

Por último, a abordagem puquiana é relacionada com a produção da Pontifícia Universidade Católica com destaque para os trabalhos de Dowbor (1999), Rico e Raichellis (1999), Cavalcanti e Nogueira (2006), Cabral (2006) e recentemente fora incluido Araújo (2012). A abordagem puquiana possui uma forte ligação com a área de serviço social e um debate marcante sobre terceiro setor e movimentos sociais.

Mesmo com o delineamento de abordagens que desenvolvem trabalhos a mais de 20 anos, Cançado (2011, p. 106) revela que "[...] foi possível identificar a tendência à banalização" do termo. Tenório (2008, p. 147) já indicava isso ao afirmar que a gestão social "[...] tem sido objeto de estudo e prática muito mais associado à gestão de políticas sociais, de organizações do terceiro setor, do combate à pobreza e até ambien- tal, do que à discussão e possibilidade de uma gestão democrática, participativa". Entretanto, também "[...] parece haver uma convergência entre alguns teóricos sobre a necessidade de um processo de gestão que seja dialógico e transparente, no qual as pessoas se comunicam livremente." (IIZUKA, GONÇALVES-DIAS; AGUERRE, 2011, p. 749).

Por fim, é importante destacar que apesar do crescimento do campo ainda existem diversas críticas que se referem às inconsistências, imprecisões conceituais, dilemas teóricos e políticos (PINHO, 2010; ARAÚJO, 2012; DIAS, 2014; JUSTEN; MORETTO NETO; GARRIDO, 2014). Por isso, considera-se a importância de realizar diálogos com os conhecimentos e as práticas sobre governança pública - esse debate pode contribuir para avançar nas lacunas existentes na gestão social, bem como nas da governança pública.

\section{Delimitando o Conceito de Governança Pública}

Nesta seção serão explorados os conceitos de governança pública, já esclarecendo, conforme Secchi (2009, p. 357): "[...] a definição de governança não é livre de contestações". Segundo o autor, isso ocorre devido as várias ambiguidades que o termo gera nas variadas áreas do conhecimento. No âmbito internacional não é diferente: a utilização de governance é variada em diferentes disciplinas como Estudos Organizacionais, Relações Internacionais, Ciência Política e Administração Pública (MORRELL, 2009). Dessa forma, são comuns as expressões: governança empresarial, corporativa, global, interativa, local, territorial, em rede, pública, organizacional, democrática, boa governança e outras adjetivações (FREY, 2004, SECCHI, 2009; DENHARDT, 2012; RAQUEL; BELLEN, 2012). Chega-se ao ponto de observar que alguns autores utilizam New Public Management e governança pública como sinônimos conforme relatam Souza e Siqueira (2007). Ainda sobre isso, "Governança é um tema abrangente e multidimensional, que tem sido pronunciado sem o devido rigor nos discursos políticos e empresariais" (SANTOS; PINHEIRO; QUEIROZ, 2014, p. 2). Pelo visto existe uma miríade de possibilidades e usos do termo e, isso pode levar ao emprego equivocado do conceito - esta observação é também pertinente à gestão social. 
Para Bizerra, Alves e Ribeiro (2012, p. 3) “[...] a temática da governança surge primeiramente no ambiente das entidades privadas". Sendo assim, antes de conceituar governança pública, aborda-se a origem dela no meio privado (governança corporativa) - percurso necessário para não empregar de forma distorcida um conceito, conforme indica Ramos (1965; 1973; 1981). Segundo Benedicto et al. (2013, p. 287): "[...] o termo governança corporativa existe há muito tempo [...]" e ganhou força na década de 1980 nos EUA e Europa. O Instituto Brasileiro de Governança Corporativa (IBGC, 2014) coloca que ela surgiu devido ao dinamismo do mercado e a expansão das transações financeiras. Logo, a governança corporativa é embasada em uma vertente financeira (FONTES FILHO; PICOLIN, 2008).

Conceitualmente, no contexto nacional é entendida como "[...] o sistema pelo qual as organizações são dirigidas, monitoradas e incentivadas, envolvendo as práticas e os relacionamentos entre proprietários, conselho de administração, diretoria e órgãos de controle [...]" (IBGC, 2014, p. 1) - possuindo como princípios fundamentais a transparência, equidade e prestação de contas (accountability) e a responsabilidade (IBGC, 2014). Especialmente, a accountability é um conceito muito caro a governança e que está sendo discutido no âmbito da administração pública no Brasil desde a década de 1990 (CAMPOS, 1990; DINIZ, 1998; PINHO; SACRAMENTO, 2009). A accountability é um termo que pode ser compreendido no sentido da transparência, da prestação de contas por parte dos governantes e ainda na responsabilização dos mesmos pelos seus atos (RAUPP; PINHO, 2011). Por isso, para Bizerra, Alves e Ribeiro (2012), existe a necessidade de incorporação dos princípios da governança no setor público.

Pelo visto, até o momento existe uma diversidade de utilização dos termos governança tanto no âmbito privado, quanto público; e essa diversidade de conceitos e concepções pode levar a armadilhas teóricas (RAQUEL; BELLEN, 2012). Nesse momento, busca-se contextualizar e delimitar alguns conceitos de governança pública.

No âmbito das relações entre Estado, mercado e sociedade, com foco no público, o uso da expressão governance surgiu em diversas abordagens e vertentes. Uma dessas foram os debates conduzidos pelo Banco
Mundial (SCOLFORO, 2013). Nessa direção, a governança se liga ao conceito de governabilidade ao ponto que "[...] a governança é primeiro determinante da governabilidade" (BENEDICTO et al., 2013, p. 288), mas, não é somente a capacidade de governar, envolve também articular os diversos atores sociais (SANTOS, 1997). São destaque, nessa linha, os códigos de boa governança (good governance) no âmbito público.

Outras origens da utilização do conceito de governança pública são destacadas nos textos de Rhodes (2009), Pierre e Peters (2000) e Bevir, Rhodes e Weller (2003) - no entanto, nestes textos, a variação da concepção de governança é também muito grande e leva, segundo Morrell (2009), a um uso frouxo do conceito e o transforma em um rótulo conveniente, além de multifacetado (FREY, 2004). É importante notar que para Kissler e Heidemann (2006) e Secchi (2009) ela surge como uma superação do modelo gerencial, no entanto, constatamos em Diniz (1998) que a governança pública é discutida desde a década de 1990 no Brasil. Outros consideram que a genealogia deste movimento retorna a década de 1980 e se desenvolveu paralelamente a administração pública gerencialista (PECI; PIERANTI; RODRIGUES, 2008; BEVIR, 2011). Osborne (2006), ao debater a New Public Governance, informa que governança e governança pública não são termos novos e possuem grande bagagem teórica e ideológica em uma diversidade de abordagens.

Buscando sistematizar, Sauerbronn (2014) apresenta três abordagens da governança: i) como governança corporativa; ii) como governança da rede de políticas públicas; e iii) governança global do desenvolvimento. É nesta última abordagem que a autora engloba as contribuições do Banco Mundial e o conceito de boa governança. Por sua vez, Osborne (2010 apud SANTOS; PINHEIRO; QUEIROZ, 2014) apresenta três escolas de governança na literatura: i) governança corporativa; ii) boa governança; e iii) governança pública. E Rhodes (1996) apresenta seis sentidos para o termo: i) Estado mínimo; ii) governança corporativa; iii) nova gestão pública; iv) boa governança; v) sistemas sociocibernéticos; e vi) redes auto-organizadas.

Para Kettl (2002), a governança pública implica um compartilhamento e responsabilização de diversos atores na busca por satisfazer as necessidades públicas, envolvendo, além do Estado (e governo), o setor 
empresarial, as organizações sem fins lucrativos e a sociedade. Nesse ínterim, um conceito de governança pública, atrelado a linha das reformas, é:

[...] uma nova geração de reformas administrativas e de Estado, que têm como objeto a ação conjunta, levada a efeito de forma eficaz, transparente e compartilhada, pelo Estado, pelas empresas e pela sociedade civil, visando uma solução inovadora dos problemas sociais $e$ criando possibilidades e chances de um desenvolvimento futuro sustentável para todos os participantes. (LÖFFER, 2001, p. 12 apud KISSLER; HEIDEMANN, 2006, p. 482)

Esse conceito ressalta a busca pela cooperação, ação conjunta, entre diversos atores, isto é, "[...] a Governança Pública está associada à dimensão sociopolítica do Estado e às políticas de desenvolvimento sociais que se fundamentam em elementos estruturais de gestão, responsabilidades, transparência e legalidade do setor público" (SCOLFORO, 2013, p. 14). E também pode ser compreendida nesse mesmo direcionamento como "[...] um mecanismo de fortalecimento das relações entre governo e comunidades locais motivadas por processos de cooperação" (PARDINI; GONÇALVES; CAMARGOS, 2013, p. 41). Coaduna com isso o posicionamento de Diniz (1998, p. 42) em que a governança envolve "[...] a capacidade de ação estatal na formulação e implementação das políticas, tendo em vista a consecução de metas coletivas".

Nas diferentes contribuições de autores para o entendimento da concepção de governança pública apresentado por Raquel e Bellen (2012), sintetiza-se que a governança pública busca a articulação em rede de diversos atores sociais públicos, privados $e$ não governamentais, enfim, relacionados ao Estado, ao mercado e à sociedade civil no intuito de gerenciar interesses e conflitos para alcançar objetivos comuns.

Para Bresser-Pereira (2001, p. 8), a "Governança Pública é um processo dinâmico pelo qual se dá o desenvolvimento político e através do qual a sociedade civil, o Estado e o governo organizam e gerem a vida pública". E, em outro momento, ao discutir as reformas do Estado afirma que "[...] é um modelo de gerência que é também um modelo de 'governança' por que envolve outros atores, além do próprio governo, no processo de governar." (BRESSER-PEREIRA, 2008, p. 394). Entretanto, para o autor a governança pública é um conceito eminentemente próximo à reforma do Estado: "[...] definirei o modelo estrutural de governança pública com base na experiência brasileira de reforma da gestão pública desde 1995." (BRESSER-PEREIRA, 2008, p. 3). Nessa linha, seu modelo de organização modelo estrutural de governança pública - é pautado em uma lógica gerencialista (PAES DE PAULA, 2005a).

Segundo Scolforo (2013), a governança pública surge em decorrência da insatisfação com o modelo gerencial. Corrobora isso a afirmação de Kissler e Heidemann (2006, p. 480) que se deve "[...] às condições insatisfatórias da modernização praticada até agora o surgimento e atratividade de um novo modelo: a governança pública (public governance)". Para Secchi (2009, p. 363), as fases dos modelos organizacionais e reformas da administração pública apresentam diversas diferenças, todavia, para o autor a maior distinção se deve à forma de tratamento do cidadão.

No modelo burocrático, o cidadão é chamado de usuário dos serviços públicos. Na retórica dos modelos APG [Administração Pública Gerencial] e GE [Governo Empreendedor], os cidadãos são tratados como clientes, cujas necessidades devem ser satisfeitas pelo serviço público. Sob o guarda-chuva da GP [Governança Pública], os cidadãos e outras organizações são chamados de parceiros ou stakeholders, com os quais a esfera pública constrói modelos horizontais de relacionamento e coordenação.

Nessa direção, Kissler e Heidemann (2006) afirmam que a governança pública está pautada em uma mudança na gestão pública. As abordagens tradicionais pautadas pela hierarquia se tornam ultrapassadas e, assim, é necessário um novo modelo (KETTL, 2002; KISSLER; HEIDEMANN, 2006). Na segunda metade do século XX, várias mudanças aconteceram em países como Nova Zelândia e Reino Unido e nos EUA na direção de uma nova forma de relacionamento entre o Estado, o mercado e a sociedade. O modelo gerencialista, no entanto, não foi democrático suficientemente (PAES DE PAULA, 2005a; 2005b). A partir do início do século XXI, a Administração Pública se tornou extremamente complexa e passa a demandar dos governos, segundo Kettl (2002), estratégias de gestão que sejam democráticas e eficientes.

Trata-se de uma tendência para se recorrer cada vez mais à autogestão nos campos social, 
econômico e político, e a uma nova composição de formas de gestão daí decorrentes. Paralelamente à hierarquia $e$ ao mercado, com suas formas de gestão à base de "poder e dinheiro", ao novo modelo somam-se a negociação, a comunicação e a confiança. Aqui a governança é entendida como uma alternativa para a gestão baseada na hierarquia. (KISSLER; HEIDEMANN, 2006, p. 483)

Diante disso, pode-se ver que o modelo da governança pública seria uma superação do modelo de administração pública gerencial e do governo empreendedor. Para outros é um modelo paralelo ou ainda sinônimo do próprio modelo gerencial. Porém, o próprio Secchi (2009) alerta que no mundo empírico a linha entre um modelo e outro é tênue.

Mesmo à frente dessas discussões, o delineamento da governança ainda não é claro, ora os autores caminham para uma definição pautada na dimensão da participação e da cooperação (um modelo de governança pública que pode ser adjetivado como democrático), e, ora pautada no gerencialismo, na eficiência e no desempenho. Não é que não sejam necessárias tais dimensões, a questão é que elas não podem ser separadas, como na clássica separação entre administração e política de Woodrow Wilson (1887). Finalmente, com base no que foi apresentado, constata-se que a governança pública é também um conceito e práticas em construção, principalmente no Brasil.

\section{Gestão Social e Governança Pública: APROXIMAÇões E (DE) LIMITAÇõES}

As discussões apresentadas estão pautadas em algumas dimensões de análise, a saber: i) racionalidade e lógica de ação; ii) protagonismo e interesse; iii) genealogia e epistemologia; iv) dinâmica e desafios do campo científico; e v) relações entre Estado, mercado e sociedade. Essas dimensões foram delineadas ao longo das revisões de literatura. Ao fim desta seção será apresentado um quadro-síntese dos principais resultados. Como as categorias apresentadas não são discutidas de forma totalmente separadas, destacando constantemente os elementos em comum e as divergências, o Quadro 1 - Dimensões de análise da Gestão
Social e da Governança Pública auxilia na visualização conjunta dos mesmos.

Primeiramente, a gestão social emerge como processo dialógico (a ação comunicativa é o tipo de ação social que a norteia; para alguns autores a ação substantiva) e o protagonismo é da sociedade (civil). Por sua vez, a governança pública surge, em parte, mimeticamente, da governança privada cuja racionalidade, como colocado por Tenório (1998), é estratégica. No setor público, ela surge pautando-se, inicialmente, pela necessidade de eficiência e transparência. Pela ótica de Bresser-Pereira (2008) o modelo estrutural de governança se aproxima do modelo gerencial pública. Nesse sentido, pela aproximação da gestão social como o modelo de administração pública societal (GUERRA; TEODÓSIO, 2012), há um distanciamento da gestão social em relação à governança pública, principalmente pelo fato de que, na governança, o Estado é protagonista das relações (BRESSER-PEREIRA, 2008) mesmo buscando a cooperação com a sociedade $e$ com o mercado.

Segundo Secchi (2009), alguns autores afirmam que a governança leva a diminuição do protagonismo estatal, porém, isso não é consenso, para outros “[...] o Estado, no entanto, não perde importância, mas sim desloca seu papel primordial da implementação para a coordenação e o controle" (SECCHI, 2009, p. 360). Diferentemente, na gestão social mesmo quando Cançado, Pereira e Tenório (2013) propõem que ela se situe em um espaço compartilhado entre Estado, mercado e sociedade, o norte ainda são as demandas da sociedade e sua emancipação. Pois, a gestão social, para Cançado, Pereira e Tenório (2013), é um contraponto à gestão burocrática do Estado e do mercado e, com isso, voltada para o interesse público não estatal. Especialmente, em França Filho (2008, p. 32, grifo nosso), o protagonismo da sociedade é evidente: "[...] [a gestão social] é o espaço próprio da chamada sociedade civil, portanto uma esfera pública de ação que não é estatal". Por sua vez, os debates sobre governança pública ligados a new public management ainda têm como locus privilegiado o Estado. Dessa forma, a governança oferece potencial de coordenação das relações entre Estado, mercado $e$ sociedade civil apenas quando passa a pensar o público como interesse público (KEINERT, 2007) e não apenas o público como interesse estatal. 
Para Kissler e Heidemann (2006, p. 485, grifo nosso) em uma estrutura de governança "[...] o Estado ativo, nos termos do modelo dos três setores, se transforma em um Estado ativador que age, principalmente, sobre o setor privado e o terceiro setor, com o propósito de mobilizar seus recursos e ativar as forças da sociedade civil". Como se observa emerge um pressuposto implícito que a sociedade civil não possui naturalmente engajamento, que precisa ser ativado pelo Estado. Diferentemente, para França Filho (2003, p. 3, grifo nosso), "[...] o termo gestão social vem sugerir assim que, para além do Estado, a gestão de demandas e necessidade do social pode se dar via a própria sociedade, através das suas mais diversas formas e mecanismos de auto-organização, especialmente o fenômeno associativo". Por isso, Justen, Moretto Neto e Garrido (2014, p. 240) interpretam que os trabalhos de França Filho $(2003 ; 2008)$ deslocam o "[...] sistema de governança pública do Estado para a sociedade".

Outros autores destacam as especificidades da lógica da gestão social. Para Araújo (2014, p. 88), "[...] prevalece a lógica humanitária, do interesse público e social, em detrimento dos interesses privados, individuais e monetário". Nesse mesmo escopo, "[...] diz respeito, portanto, a uma forma de gestão organizacional que do ponto de vista de sua racionalidade pretende subordinar as lógicas instrumentais a outras lógicas mais sociais, políticas, culturais ou ecológicas." (FRANÇA FILHO, 2003, p. 3). Portanto, é possível constatar uma crítica ao modelo capitalista vigente na direção da economia solidária - principalmente nos trabalhos do professor Genauto Carvalho de França Filho (PERES JR.; PEREIRA, 2014). Aqui, a gestão social busca formas de superar a ideologia do mercado $e$ sua lógica enquanto a governança pública se aproxima dela de forma cooperativa e mimética. Secchi (2009) esclarece que os modelos organizacionais, incluindo a governança, não são modelos de ruptura. Desse modo, a gestão social se apresenta como um projeto mais radical no sentido da Teoria Crítica (TENÓRIO, 1998), e que, apesar das críticas (DIAS, 2014), busca ser um projeto político alternativo (FREITAS; FREITAS; FERREIRA, 2014). Para Subirats (2007, p. 627), a gestão social possui "[...] um grande potencial transformador, que vai além da captura tecnocrática que do termo 'governance' as grandes organizações internacionais foram fazendo".
Na gestão social, a sociedade como protagonista pode ser referenciada em Habermas (2011), segundo o qual os médiums do Estado (poder administrativo) e do mercado (dinheiro) não são compatíveis com a emancipação (ANDREWS, 2011). Dessa forma, essa primeira visão de governança pública (relacionada à new public management) naturaliza o Estado como entidade monolítica e não permeada por relações de interesses e conflitos que, muitas vezes, não convergem com os interesses da sociedade (no sentido republicano do bem comum) e das organizações da sociedade civil. Diferente disso, a orientação das ações da gestão social deve ser focada no interesse público não estatal (democrático), e, assim, esse interesse público pode divergir dos interesses do Governo, do mercado e seus atores. Portanto, com base no texto de Bresser-Pereira (2008), ainda há uma distância entre a governança pública e a gestão social.

A governança também envolve um processo,
mas um processo mais amplo, na medida em
que transmite a idéia de que as organizações
públicas não-estatais ou as organizações da
sociedade civil, empresas comerciais, cidadãos
individuais e organizações internacionais tam-
bém participam do processo de tomada de
decisões, embora o governo continue sendo
o ator central. (BRESSER-PEREIRA, 2008, p.
400 , grifo nosso)

Rhodes (1996) defende que o Estado não é mais supremo e passa a ser um Estado ativador e não mais provedor (KISSLER; HEIDEMANN, 2006). Essa perspectiva se afasta da perspectiva neoliberal da governança e se refere à vertente da governança como redes (BEVIR; RHODES; WELLER, 2003; RHODES, 1997). Essa vertente, na perspectiva de Bevir (2011), se relaciona à Terceira Via, a governança joined-up e redes, à parcerias e não à New Public Management. Mesmo assim, Paes de Paula (2005a) defende que a governança não consegue superar a dicotomia entre administração e política: "[...] a governança não assimilou adequadamente a dimensão sociopolítica da gestão, pois atualmente a prática da governança ainda se reduz à abordagem tecnocrática e tem uma visão excessivamente estreita da política." (PAES DE PAULA, 2005a, p. 79, grifo nosso). A autora realiza essa crítica mesmo considerando as perspectivas de Rhodes (1996) e Diniz (1997), que elaboram um conceito mais amplo e democrático da governança. 
Um ponto importante frisado por Kissler e Heidemann (2006, p. 486) é que o modelo de governança pública trouxe como consequência uma mercadização do setor público, isto é, "[...] a transformação do setor público em um empreendimento econômico". Isso é importante, pois pela lente da gestão social o Estado $e$ as atividades diretamente ligadas ao público não podem seguir a mesma lógica do mercado (ação estratégica). Por isso, Tenório (1998) pontua que "[...] a epistemologia de desenvolvimento da gestão social não pode ser pautada por mecanismos de mercado que orientam a gestão estratégica". Guerreiro Ramos (1981) já alertava sobre os problemas do crivo do mercado, e Habermas (2012), em Teoria do Agir Comunicativo, ressalta a influência (colonizadora) do mercado com seu médium nas demais esferas da vida social (ANDREWS, 2011). Por essa linha, em termos normativos, a governança pública está mais para o "mundo do sistema" do que para o "mundo da vida" (ANDREWS, 2011; HABERMAS, 2012). Segundo Bauer e Carrion (2010), a gestão social não se coaduna na transposição dos princípios e dos postulados da gestão privada para outros campos sociais. Finalmente, consoante Cançado, Tavares e Dallabrida (2013), a governança (territorial) contribui para a gestão social, no entanto, distancia-se pelas suas vertentes ligadas ao modelo gerencial.

Algumas noções de governança pública se confundem com a perspectiva neoliberal (PECI; PIERANTI; RODRIGUES, 2008), todavia, para os autores governança é um conceito essencialmente democrático. Constata-se que a governança é multifacetada e plural e, por isso, para se aproximar da gestão social, é preciso romper com um discurso participativo (dos próprios modelos gerenciais) que "[...] não aponta canais que permitiriam a infiltração das demandas populares." (PAES DE PAULA, 2005a, p. 147). Assim, superando uma concepção inicial de governança, aborda-se uma vertente mais democrática da governança pública como entendida por Diniz (1998; 2013), Frey (2004), Bevir (2011) e outros. Nesse sentido, são importantes os conceitos de governança democrática (BALLESTEROS, 2012; SILVA; LASMAR; PEREIRA, 2013), governança democrática em rede (DENHARDT, 2012), governança pública democrática (SCOLFORO, 2013), governança participativa (CANÇADO; SAUSEN; VILLELA, 2013), ou a adjetivação governança deliberativa (FREITAS; FREITAS; DIAS, 2012).
Os princípios da transparência, da accountabilitye da responsabilização são acoplados a uma concepção democrática mais ampla. Estes, além do pluralismo, autonomia e participação, passam a ser princípios comuns na gestão social e na governança pública. Bevir (2011) realiza uma genealogia do conceito de governança democrática. O autor sugere a necessidade de uma renovação democrática por meio da participação pública e considera que a governança busca uma cidadania pluralista, uma democracia participativa e a elaboração de políticas públicas de forma dialógica (BEVIR, 2011). Nesse cenário, para Tenório et al. (2008, p. 2), "[...] a operacionalização da governança democrática combina a ação interorganizacional - reconhecida como um componente integral da efetivação de várias políticas". Assim, foi possível para Villela e Pinto (2009) afirmarem que existe relação entre a governança pública e a racionalidade comunicativa. Todavia, para isso é preciso entender a governança pública como "[...] a prática de uma gestão compartilhada de processos decisórios que conduz, a partir do consenso, as deliberações de uma dada rede, objetivando articular e facilitar ações do projeto de desenvolvimento traçado pelos próprios participantes [...]" (VILLELA; PINTO, 2009, p. 1075) $e$, nesse caminho, governança participativa se refere a uma administração dialógica de coordenação dos atores. Especialmente, no que se refere à cidadania, a gestão social utiliza o conceito de cidadania deliberativa - que necessita para se consolidar de processos de discussão, inclusão, pluralismo, igualdade participativa, autonomia e bem comum (TENÓRIO et al., 2008; TENÓRIO, 2005; 2012).

No que se refere à posição mencionada existe uma aproximação pelo conceito apresentado por Matias-Pereira (2010, p. 113), ao conceituar governança pública como "[...] o sistema que determina o equilíbrio de poder entre todos os envolvidos numa organização governantes, gestores, servidores, cidadãos - com vista a permitir que o bem comum prevaleça sobre os interesses de pessoas ou grupos". E, também, pela forma como Diniz (2013, p. 17) entende a governança: "[...] formas de gestão caracterizadas pela capacidade de construir instâncias de interlocução com a sociedade, voltadas para definir as prioridades da agenda pública, abrindo espaço para a consecução das metas coletivas e a sustentação política das decisões tomadas". Assim, a governança pública (democrática) pode contribuir 
para o desenvolvimento da gestão social ao indicar práticas e conhecimentos de coordenação de ações entre Estado, mercado e sociedade civil.

Quanto ao campo de debates, observa-se que ambos ainda não apresentam consenso em diversas questões, tanto a gestão social quanto a governança pública. Sobre esta última, "[...] não existe um conceito único de governança pública [...] Pairam dúvidas não somente sobre as bases de cooperação entre esses atores, mas também sobre seus resultados." (KISSLER; HEIDEMANN, 2006, p. 480). Nesse ponto, a gestão social também enfrenta seus dilemas e críticas (CANÇADO; PEREIRA; TENÓRIO, 2013). Araújo (2012), por exemplo, destaca a multiplicidade de sentidos e inconsistências do campo da gestão social e Justen, Moretto Neto e Garrido (2014) afirmam que é uma narrativa plural e que precisa enfrentar diversas lacunas para realmente se constituir como um processo emancipatório. Portanto, tanto a gestão social quanto a governança pública ainda são debatidas conceitualmente e no escopo das evidências empíricas. No caso da governança pública, os debates são construídos dentro da Administração Pública e da Ciência Política e, apesar de uma tradição nacional (DINIZ, 1998), os debates no Brasil ainda são incipientes se comparado a países da Europa (em especial, Reino Unido, Holanda e Alemanha) e Estados Unidos. Adiante, a tradição da governança pública ainda é funcionalista e se aproxima da perspectica crítica em Denhardt (2012) nas suas adjetivações democrática, participativa e deliberativa. A gestão social está sendo construída como um conceito nacional (mesmo com práticas e conhecimentos existentes em diversos países da América Latina) no âmbito da Administração e também da Administração Pública e Serviço Social. Segundo Cançado et al. (2011, p. 129), "[...] apesar de ser um campo em construção, nota-se que já existem certas tendências em consolidação". Epistemologicamente, a gestão social surge com Tenório (2008) no âmbito da Teoria Crítica, especialmente, na tradição habermasiana.

As características da gestão social advindas da Teoria Crítica estão diretamente relacionadas ao conceito de emancipação social, a crítica ao funcionalismo $e$ à racionalidade instrumental que fundamentam as abordagens tradicionais da administração e da administração pública. Verifica-se a influência habermasiana nos conceitos e pressupostos da gestão social quando se considera e se utiliza da dialogicidade, da democracia deliberativa, da esfera pública e da racionalidade comunicativa. Nesse sentido, é possível ressaltar que a principal influência habermasiana para o entendimento da gestão social ocorre em relação ao que Habermas (2011) denomina de formação da opinião pública, pois os processos comunicativos públicos no âmbito das relações entre Estado, sociedade e mercado constituem um fluxo de forças capazes de influenciar as decisões políticas. Por isso, a gestão social, conceituada sob a ótica habermasiana, é definida como uma ação gerencial dialógica voltada para o interesse público não estatal e para o bem comum, no sentido de alcançar a emancipação social (CANÇADO; PEREIRA; TENÓRIO, 2013). Portanto, a participação social nas decisões políticas (via esferas públicas) é um traço comum entre a abordagem habermasiana e a gestão social como resultado dos processos dialógicos de formação da opinião pública.

Por fim, no que tange às relações entre Estado, mercado e sociedade civil existem também proximidades. Para Sousa et al. (2014, p. 28), "[...] no contexto da gestão social, a governança é tratada como mecanismo de integração entre Estado, mercado e/ ou sociedade". Adiante, tanto a gestão social quanto a governança pública consideram a importância da relação e da coordenação das ações desses atores sociais. Primeiramente, a gestão social destaca que essas relações devem ser permeadas pelos princípios da inclusão, do pluralismo, da igualdade participativa, da autonomia e do bem comum. Em consonância, a governança pública destaca accountability, transparência, responsabilização e a participação dos três setores de forma plural e coordenada - é notório que as duas abordagens compartilham de diversos princípios, valores em comuns, tal como práticas. Nesse contexto, é destacada a existência de espaços de participação $e$, especialmente, na gestão social a importância da constituição de esferas públicas politizadas e com poder de influência no sistema político.

Ainda no que se refere às relações entre Estado, mercado e sociedade, outra importante aproximação é entre redes na governança pública e interorganizações na gestão social (BENEDICTO et al., 2013; SILVA; LASMAR; PEREIRA, 2013). O conceito de interorganizações se relaciona com território, redes e redes de redes e vem sendo desenvolvido por Fischer 
(2004; 2012) e Fischer, Melo e Codes (2004). Segundo Fischer (2012, p. 114), "[...] as interorganizações são constituídas por organizações diferenciadas, conectadas por propósitos comuns, isto é, integradas. A associação se faz pela complementaridade - portanto, pela busca do diferente que possa cooperar para se atingir um resultado", daí, algumas diferenças com o conceito de redes (CANÇADO, 2011). Bevir, Rhodes e Weller (2003) e Rhodes (1997) destacam a governança pública como um caminho para formas não hierárquicas e a prática de redes. Sørensen e Torfing (2008 apud DENHARDT, 2012) enfatizam também o papel das redes destacando a articulação horizontal $e$ a interdependência dos atores.

Maia (2005) destaca que os textos de Fischer (abordagem do desenvolvimento social para Peres Jr. e Pereira, 2014), Dowbor e Carvalho (abordagem puquiana) destacam a governança como possível caminho de viabilização da gestão social, isto é, a gestão social pode ser "implementada" por meio de arranjos de governança. Além disso, mediante a sistematização de Maia (2005), é possível considerar também que pela diversidade de focos, locos, agentes e própositos da gestão social, a governança pública encontra respaldo em várias práticas e conceitos que constituem o cerne daquela, tal como: valores (democracia e cidadania), propósitos (desenvolvimento, democratização), agentes (organizações sociais, sociedade civil, governos), dentre outras possibilidades.

Outra discussão importante são as parcerias público-privadas e com as organizações da sociedade civil como destaca Kissler e Heidemann (2006) e discutido na gestão social por Teodósio (2008) ao tratar das parcerias trissetoriais na esfera pública. Destacase, além disso, que uma forma de possível interação entre Estado, mercado e sociedade é a coprodução de bens e serviços públicos (MATTIA; ZAPPELLINI, 2014). Segundo esses autores, no Brasil, a coprodução (que inicialmente estava discutida no âmbito da New Public Management) passou a ser tratada sob a ótica da governança pública e do novo serviço público na direção da participação cidadã (DENHARDT, 2012). Com base em Mattia e Zappellini (2014), destaca-se a possibilidade de aproximar a gestão social e a governança pública também por meio da coprodução, pois os autores consideram que a coprodução tem a ganhar com a lógica da gestão social como um processo participativo e dialógico - essa consideração é apresentada no fim deste trabalho como uma possibilidade de ampliar as discussões entre governança pública e gestão social.

Finalmente, o Quadro 1 apresenta uma síntese procurando mostrar alguns elementos de cada conceito e suas aproximações. É conveniente ressaltar que as polarizações são realizadas com base nas concepções (hegemônicas) encontradas. Destaca-se que, no quadro, o conceito de gestão social utilizado está relacionado diretamente à abordagem denominada de frankfurtiana, e a concepção de governança ligada diretamente aos modelos, próximo ao gerencial, mesmo que na tentativa de super-lo; as aproximações, por sua vez, destacam as concepções mais democráticas da governança pública (participativa e deliberativa).

\begin{tabular}{|c|c|c|c|}
\hline \multirow{2}{*}{ Dimensão } & Gestão Social & Aproximações & Governança Pública \\
\hline & \&............ & & \\
\hline $\begin{array}{l}\text { Racionalidade e } \\
\text { lógica de ação }\end{array}$ & $\begin{array}{c}\text { Ação comunicativa; } \\
\text { Racionalidade substantiva e } \\
\text { comunicativa; } \\
\text { Dialogicidade }\end{array}$ & $\begin{array}{l}\text { Racionalidade comunicativa; } \\
\text { Descentralização }\end{array}$ & $\begin{array}{l}\text { Ação estratégica; } \\
\text { Eficiência - Eficácia; } \\
\text { Tecnocracia }\end{array}$ \\
\hline $\begin{array}{c}\text { Protagonismo e } \\
\text { interesse }\end{array}$ & $\begin{array}{c}\text { Sociedade [civil]; } \\
\text { Interesse público não estatal; } \\
\text { Público como interesse público; } \\
\text { Modelo societal }\end{array}$ & $\begin{array}{l}\text { Participação; Democracia; } \\
\text { Interesse público; } \\
\text { Cooperação; Transparência; } \\
\text { Pluralismo; Autonomia }\end{array}$ & $\begin{array}{c}\text { Estado; } \\
\text { Interesse público estatal; } \\
\text { Público como interesse estatal; } \\
\text { Modelo gerencial }\end{array}$ \\
\hline $\begin{array}{l}\text { Genealogia e } \\
\text { epistemologia }\end{array}$ & $\begin{array}{c}\text { Teoria Crítica - Habermas; } \\
\text { Potencial crítico; } \\
\text { Abordagem da gestão }\end{array}$ & $\begin{array}{l}\text { Governança democrática; } \\
\text { Governança deliberativa; } \\
\text { Governança participativa }\end{array}$ & $\begin{array}{c}\text { Governança corporativa; } \\
\text { Mecanismos do mercado; } \\
\text { Modelo regulatório }\end{array}$ \\
\hline $\begin{array}{l}\text { Dinâmica e desafios } \\
\text { do campo científico }\end{array}$ & $\begin{array}{l}\text { Administração Pública; } \\
\text { Administração; } \\
\text { América Latina - Brasil }\end{array}$ & $\begin{array}{l}\text { Pluralidade conceitual; } \\
\text { Imprecisões; Ampliação; } \\
\text { Evidências empiricas }\end{array}$ & $\begin{array}{l}\text { Administração Pública; } \\
\text { Ciência Política; } \\
\text { Europa - Estados Unidos }\end{array}$ \\
\hline $\begin{array}{c}\text { Relações entre } \\
\text { Estado, mercado e } \\
\text { sociedade }\end{array}$ & $\begin{array}{l}\text { Da sociedade para o Estado; } \\
\text { A partir do mundo da vida; } \\
\text { Esfera pública }\end{array}$ & $\begin{array}{c}\text { Parcerias; } \\
\text { Coprodução do bem público; } \\
\text { Diversidade de atores; } \\
\text { Terceiro setor }\end{array}$ & $\begin{array}{l}\text { Do Estado para a sociedade; } \\
\text { A partir do mundo do sistema; } \\
\text { Novo modelo regulatório }\end{array}$ \\
\hline
\end{tabular}

Quadro 1: Dimensões de análise da Gestão Social e da Governança Pública

Fonte: Elaborado pelos autores deste artigo 
Por fim, destaca-se que este quadro não tem por intenção palarizar ou dicotomizar a relação entre gestão social e governança pública. As relações cooperativas (complementaridades) entre esses conceitos possuem potencial relevante para a construção democrática da gestão nas diversas esferas da vida em sociedade (Estado, mercado e sociedade civil).

\section{Considerações Finais}

Foram abordadas neste ensaio teórico as aproximações e as delimitações teórico-conceituais entre gestão social e governança pública. Para tanto, buscou-se, na redução sociológica de Guerreiro Ramos (1965; 1981), a possibilidade de articulações teórico-conceituais, no intuito de não transpor, nem deformar conceitos com matrizes epistemológicas distintas. Neste ensaio, a redução foi um filtro crítico que possibilitou debater os conceitos, aproximá-los e distanciá-los, levando em consideração suas origens e seu desenvolvimento. De forma geral, foram direcionadas as análises para as categorias racionalidade e lógica de ação; protagonismo e interesse; genealogia e epistemologia; dinâmica e desafios do campo científico e relações entre Estado, mercado e sociedade.

Uma das reduções realizadas foi para analisar comparativamente gestão social e governança pública. Com base em Paes de Paula (2005a; 2005b), a gestão social é uma abordagem da gestão coerente com o "modelo societal" e, pela maior parte da literatura, a governança pública é apresentada como um "modelo regulatório" cuja abordagem de gestão se encontra em diversas posições entre o gerencialismo $e$ a gestão social. Em consequência disso, existem diferenças na escala de aplicabilidade, em que a gestão social foca relações interpessoais/intersubjetivas (e locais) e a governança pública se volta essencialmente para níveis mais amplos denotados pela expressão "modelo regulatório" (KISSLER; HEIDEMANN, 2006). Contudo, a recente discussão de Cançado, Pereira e Tenório (2015), sobre a escalaridade da gestão social, se propõe a debater se ela está confinada à escala local ou pode ser ampliada. Por isso, sem compreender essas especificidades não é possível comparar uma "abordagem de gestão" com um "modelo regulatório". Além desse sentido, como campo de conhecimento, é importante destacar que a gestão social inclui conhecimentos/práticas sobre políticas públicas, inovação social, território, desenvolvimento, economia solidária, dentre outros.

Outro filtro crítico foi aplicado ao conceito de governança que, além de originar-se no meio empresarial, tem se desenvolvido mais efetivamente na Europa e nos Estados Unidos e nas áreas de Administração Pública e Ciência Política (RAQUEL; BELLEN, 2012) - no Brasil, essa discussão se iniciou na década de 1990, mas ganhou amplitude de debate recentemente (DINIZ, 1998; SECCHI, 2009). Em contrapartida, a gestão social, apesar das influências das obras estrangeiras, é um conceito que se desenvolveu nacionalmente, principalmente, na Administração, Administração Pública e Serviço Social. Mesmo assim, Cançado, Tavares e Dallabrida (2013, p. 316) citando Tenório (2010) destacam que a origem do termo "[...] vem de reuniões e cursos realizados nos Estados Unidos e na América Latina com a intenção de capacitar gestores públicos". Outros autores destacam sua existência no Chile, Guatemala e Panamá (ARAÚJO, 2012; CANÇADO; TAVARES; DALLABRIDA, 2013). Por isso, buscou-se para a gestão social, como para a governança pública, a origem dos conceitos e os diversos debates presentes nos respectivos campos de estudo - que convergem $e$ divergem. Um ponto nevrálgico foi a ambiguidade de conceitos relacionados à governança pública, principalmente, em decorrência da relação com o setor privado e da aproximação com o modelo gerencial (BRESSER-PEREIRA, 2008), e, por outro lado, rompendo com ele (KISSLER; HEIDEMANN, 2006; SECCHI, 2009). Todavia, tanto a gestão social quanto a governança pública ainda apresentam diversos conceitos: "[...] o entendimento que se tem sobre governança pública não é muito claro [...]" (KISSLER; HEIDEMANN, 2006, p. 480), como o de gestão social também não é (CANÇADO, 2011; ARAÚJO, 2012).

Contudo, é possível que a gestão social ajude a responder ou problematizar alguns questionamentos da governança pública - além das respostas dadas por Kissler e Heidemann (2006) - tanto na teoria quanto na prática e, por outro lado, alguns mecanismos da governança podem ser utilizados pelos gestores sociais. Mas, sabe-se que alguns desses mecanismos advêm da governança corporativa e, portanto, precisam ser pensados retirando-se todos os elementos acessórios e, assim, mesmo sendo desenvolvidos em outros países 
ou áreas do conhecimento, com a imposição de um filtro crítico é possível a sua utilização teórica e prática. Logo, a gestão social pode se aproximar da governança pública buscando mecanismos e meios de organização somente se esta mantiver o fim na emancipação e os meios (processos) baseados no diálogo, na participação e na deliberação. Do ponto de vista da gestão social, é possível se apropriar de diversos processos, princípios e critérios difundidos pela governança, no entanto, sugere-se a adequação por meio da redução sociológica como a realizada por Tenório et al. (2010) para critérios de avaliação de processos decisórios participativos deliberativos. A governança pública, por sua vez, pode buscar complementaridades nos processos gerenciais dialógicos voltados para o bem comum e ampliar as possibilidades de participação da sociedade nos processos decisórios.

Sinteticamente, considera-se que os dois conceitos são distintos devido às origens ontológicas e epistemológicas também distintas, mas que apresentam elementos constitutivos comuns - aplicando uma noção da proposta de Faria (2012) - para as matrizes epistemológicas). A governança pública se aproxima da gestão social no que diz respeito aos princípios e às práticas da transparência, autonomia, pluralismo, participação e bem comum, tal como na orientação das ações por meio do interesse público e na cooperação entre Estado, mercado e sociedade. Aliás, outro ponto em comum é a concepção de sociedade civil e a visão tripartite (Estado, mercado e sociedade civil) que se aproximam de visões presentes em Cohen e Arato (1992) e Habermas (2011), distanciando-se de perspectivas hegelianas, marxistas e gramscianas.

Por outro lado, os conceitos se distanciam no que diz respeito ao protagonismo das ações e à sua orientação específica: na governança pública a orientação das ações é o interesse público estatal e o protagonismo é do Estado; na gestão social a orientação das ações é o interesse público não estatal e o protagonismo é da sociedade. O estudo evidencia também que a gestão social e a governança pública se distanciam principalmente pela vertente da governança vinculada a New Public Management e se aproximam nas vertentes democráticas/participativas e menos tecnicistas/tecnoburocráticas que podem ser relacionadas ao modelo societal.
Por fim, é importante lembra-se de que, devido às origens distintas dos conceitos, deve haver também alguns distanciamentos (BERGUE, 2013). O próprio Guerreiro Ramos (1973, p. 16) adverte que "[...] há regras com relação a conceitos: a formação original nunca pode ser abolida". E, ainda, Faria (2012) alerta que a utilização de conceitos de matrizes epistemológicas diferentes pode levar a incoerências. Esses debates são importantes, pois, no contexto nacional, Paes de Paula (2005a; 2005b) ressalta que muitos conceitos acabaram sendo transpostos de forma indevida e que isso acompanhou a história da gestão empresarial e pública no Brasil. Finalmente, destaca-se que, na última parte de seu artigo, Kissler e Heidemann (2006, p. 498) afirmam que "[...] aqueles que optarem pela governança pública terão pela frente um caminho longo e árduo [...]" - essa consideração é propriamente válida também para a gestão social.

Como limitações, pode-se destacar a abordagem assistemática da literatura e as possibilidades de interpretações unidirecionais, afinal, é possível assumir que "[...] quando nos empenhamos em esforços de formulação teórica é frequente expormo-nos ao risco de incorrer na transferência inadequada de conceitos" (RAMOS, 1973, p. 8). À frente, a abordagem frankfurtiana da gestão social foi a mais explorada em detrimento das outras existentes e, na tentativa também de incluir o outro, parte-se de várias críticas à governança pública. Em relação a uma agenda de pesquisa, é possível destacar três possibilidades: i) empreender em uma pesquisa sistemática que operacionalize uma discussão teórica de interfaces entre gestão social e governança pública a partir das dimensões constitutivas desses conceitos; ii) investigar práticas de gestão social e governança pública no Brasil e em que medida elas são empiricamente distintas e empiricamente complementares; iii) estudar o modelo de coprodução do bem público como uma das possibilidades de síntese das aproximações entre a gestão social e a governança pública. Essas pesquisas poderão contribuir com a construção e a consolidação dos campos de estudo/matrizes epistemológicas da gestão social e da governança pública e suas interfaces. 


\section{REFERÊNCIAS}

ANDREWS, C. W. Emancipação e legitimidade: uma introdução à obra de Jürgen Habermas. São Paulo: Editora Unifesp, 2011.

ANDREWS, C. W.; KOUZMIN, A. O discurso da Nova Administração Pública. Lua Nova, [S.l.], n. 45, p. 97-129, 1998.

ARAÚJO, E. T. (In)consistências da gestão social e seus processos de formação: um campo em construção. 2012. 257 f. Tese (Doutorado em Serviço Social) Pontifícia Universidade Católica de São Paulo, São Paulo, 2012.

ARAÚJO, E. T. Gestão Social. In: BOULLOSA, R. F. (Org.). Dicionário para a formação em gestão social. Salvador: CIAGS, v. 1, p. 85-90, 2014.

BALLESTEROS, P. K. R. Governança democrática: por uma nova perspectiva de análise e construção das políticas de segurança pública no Brasil. 2012. 143 f. Dissertação (Mestrado em Administração) - Escola de Administração de Empresas de São Paulo, São Paulo, 2012.

BARBOSA, M. A. C. et al. Nem só de debates epistemológicos vive o pesquisador em administração: alguns apontamentos sobre disputas entre paradigmas $e$ campo científico? Cadernos EBAPE.BR, [S.l.], v. 11, p. 636-651, 2013.

BAUER, M. A. L.; CARRION, R. S. M. Gestão Social do Território: entre a ideologia e a utopia. In: IV ENCONTRO NACIONAL DE PESQUISADORES EM GESTÃO SOCIAL, 2010. Anais... Lavras, Encontro Nacional de Pesquisadores em Gestão Social: Lavras, 2010.

BENEDICTO, S. C. et al. Governança corporativa: uma análise da aplicabilidade dos seus conceitos na administração pública. Organizações Rurais \& Agroindustriais, [S.l.], v. 15, p. 286-300, 2013.

\section{BERGUE, S. T. Modelos de gestão em organizações} públicas: teorias e tecnologias gerenciais para análise e transformação organizacional. Caxias do Sul: Educs, 2011.
BERGUE, S. T.; KLERING, L. R. A Redução sociológica no processo de transposição de tecnologias gerenciais.

Organizações \& Sociedade, [S.l.], v. 17, p. 138-156, 2010.

BERGUE, S. T. Gestão estratégica e políticas públicas: aproximações conceituais possíveis e distanciamentos necessários. Contabilidade, Gestão e Governança, [S.l.], v. 16, n. 2, p. 77-93, 2013.

BERTERO, C. O.; CALDAS, M. P.; WOOD JUNIOR, T. Produção científica em administração de empresas: provocações, insinuações e contribuições para um debate local. Revista de Administração Contemporânea, [S.l.], v. 3, n. 1, p. 147-178, 1999.

BEVIR, M.; RHODES, R. A. W.; WELLER, P. Comparative governance: prospects and lessons. Public Administration, [S.l.], v. 81, p. 191-210, 2003.

BEVIR, M. Governança democrática: uma genealogia. Revista de Sociologia e Política, [S.1.], v. 19, n. 39, p. 103-114, 2011.

BIZERRA, A.; ALVES, F. J. S.; RIBEIRO, C. M. A. Governança pública: uma proposta de conteúdo mínimo para os relatórios de gestão das entidades governamentais. In: ENCONTRO DE ADMINISTRAÇÃO PÚBLICA E GOVERNO, Bahia, 2012. Anais... Salvador: ANPAD, 2012

BRESSER-PEREIRA, L. C. Uma nova gestão para um novo Estado: liberal, social e republicano. Revista do Serviço Público, [S.l.], v. 52, n. 1, p. 5-24, 2001.

BRESSER-PEREIRA, L. C. O modelo estrutural de gerência pública. Revista de Administração Pública, [S.l.], v. 42, n. 2, p. 391-410, 2008.

CABRAL, E. H. S. Espaço público e controle para a gestão social no Terceiro Setor. Serviço Social e Sociedade, [S.I.], v. 86, p. 30-55, 2006.

CAMPOS, A. M. Accountability: quando poderemos traduzi-la para o português? Revista de Administração Pública, [S.l.], v. 24, n. 2, p. 30-50, 1990.

CANÇADO, A. C. Fundamentos teóricos da gestão social. 2011. 315 f. Tese (Doutorado em Administração) - Universidade Federal de Lavras, Lavras, 2011. 
CANÇADO, A. C. Gestão social: um debate para a construção do campo. NAU Social, [S.l.], v. 4, p. 191209, 2013.

CANÇADO, A. C.; TENÓRIO, F. G.; PEREIRA, J. R. Gestão social: reflexões teóricas e conceituais. Cadernos EBAPE.BR, [S.l.], v. 9, n. 3, p. 681-703, 2011.

CANÇADO, A. C. et al. Gestão social: conhecimento e produção científica nos ENAPEGS 2007-2010.

Administração Pública e Gestão Social, [S.l.], v. 3, n. 2, p. 1-23, 2011.

CANÇADO, A. C.; PEREIRA, J. R.; TENÓRIO, F. G. Gestão Social: epistemologia de um paradigma. Curitiba: Editora CRV, 2013.

CANÇADO, A. C.; PEREIRA, J. R.; TENÓRIO, F. G. Gestão Social: epistemologia de um paradigma. 2. ed. Curitiba: Editora CRV, 2015.

CANÇADO, A. C.; SAUSEN, J. O.; VILLELA, L. E. Gestão social versus gestão estratégica. In: TENÓRIO, F. G. (Org.). Gestão social versus gestão estratégica: experiências em desenvolvimento territorial. Rio de Janeiro: Editora FGV, 2013. p. 15-99.

CANÇADO, A. C.; TAVARES, B.; DALLABRIDA, V.

R. Gestão social e governança territorial: interseções e especificidades teórico-práticas. Revista Brasileira de Gestão e Desenvolvimento Regional, [S.l.], v. 9, p. 313-353, 2013.

\section{CAVALCANTI, M.; NOGUEIRA, A. Gestão social,} estratégias e parcerias: redescobrindo a essência da administração brasileira de comunidades para o Terceiro Setor. São Paulo: Saraiva, 2006.

\section{COHEN, J.; ARATO, A. Civil Society and Political}

Theory. MIT Press. Cambridge, 1992.

\section{DENHARDT, R. Teoria Geral de Organizações}

Públicas. 6. ed. São Paulo: Cengage Learning, 2012.

DIAS, V. T. Gestão Social e Terceiro Setor: contribuições críticas a partir da noção de Estado em Gramsci. In: ENCONTRO NACIONAL DE PESQUISADORES EM GESTÃO SOCIAl, 2014, Anais... Cachoeira, RGS: ENAPEGS, 2014.
DIEFENBACH, T. New Public Management in public sector organizations: the dark sides of managerialistic enlightenment. Public Administration, [S.I.], v. 87, n. 4, p. 892-909, 2009.

DINIZ, E. Crise, reforma do Estado e governabilidade. Rio de Janeiro: FGV, 1997.

DINIZ, E. Uma perspectiva analítica para a reforma do Estado. Lua Nova, [S.I.], n. 45, p. 29-48, 1998.

DINIZ, E. Desenvolvimento e Estado desenvolvimentista: tensões e desafios da construção de um novo modelo para o Brasil do século XXI. Revista de Sociologia e Política, [S.l.], v. 21, n. 47, p. 9-20, 2013.

DOWBOR, L. Tendências da gestão social. Saúde e Sociedade, [S.I.], v. 8, n. 1, p. 3-16, 1999.

ARAÚJO, E. T.; FRANÇA FILHO, G. C.; BOULLOSA, R. F. Sobre o ENAPEGS. 2014. Disponível em: < http:// www3.ufrb.edu.br/enapegs/sobre-o-enapegs.html>. Acesso em: 4 fev. 2015.

FARIA, J. H. Consciência crítica com ciência idealista: paradoxos da redução sociológica na fenomenologia de Guerreiro Ramos. Cadernos EBAPE.BR, [S.l.], v. 7, p. 419-446, 2009.

FARIA, J. H. Dimensões da Matriz Epistemológica em Estudos em Administração: uma proposição. In: XXXVI ENCONTRO DA ANPAD. Rio de Janeiro, 2012. Anais... Rio de Janeiro: ANPAD, 2012.

FISCHER, T. Organizações e interorganizações na gestão do desenvolvimento socioterritorial. Organizações e Sociedade, [S.1.], v. 11, p. 13-41, 2004.

FISCHER, T.; MELO, V. P.; CODES, A. L. Integração e gestão do desenvolvimento sócio-territorial: um estudo de organizações da sociedade civil em municípios baianos. In: XXVIII ENCONTRO DA ANPAD. Paraná, 2004.

Anais... Curitiba: ANPAD, 2004.

FISCHER, T. et al. Perfis visíveis na gestão social do desenvolvimento. Revista de Administração Pública, [S.l.], v, 40, n. 5, p. 789-808, 2006.

FISCHER, T. Gestão social do desenvolvimento de territórios. Revista Psicologia, [S.l.], v. 12, n. 1, p. 113119, 2012. 
FONTES FILHO, J. R.; PICOLIN, L. M. Governança corporativa em empresas estatais: avanços, propostas e limitações. Revista Brasileira de Administração Pública, [S.l.], v. 42, n. 6, p. 1.163-2.288, 2008.

FRANÇA FILHO, G. C. Gestão social: um conceito em construção. In: COLÓQUIO INTERNACIONAL SOBRE PODER LOCAL, Bahia. Anais... Salvador: UFBA, 2003.

FRANÇA FILHO, G. C. Definindo gestão social. In: SILVA JÚNIOR et al. (Org.). Gestão social: práticas em debate, teorias em construção. Fortaleza: Imprensa Universitária, 2008. p. 26-37.

FREITAS, A. F; FREITAS, A. F. FERREIRA, M. A. M. Gestão social como projeto político e prática discursiva. In: VI ENCONTRO DE ADMINISTRAÇÃO PÚBLICA E GOVERNANÇA, 2014, Anais... Belo Horizonte, ANPAD, 2014.

FREITAS, A. F; FREITAS, A. F; DIAS, M. M. O colegiado de desenvolvimento territorial no contexto da descentralização da gestão de políticas públicas. Revista de Administração Pública, [S.l.], v. 46, p. 1.201-1.223, 2012.

FREY, K. Governança interativa: uma concepção para compreender a gestão pública participativa? Política \& Sociedade, [S.l.], v. 5, p. 117-136, 2004.

GUERRA, J. F. C.; TEODÓSIO, A. S. S. Gestão Pública Societal e Gestão Social: análise de aproximações e distanciamentos na práxis de uma política pública.

Pensamento \& Realidade, [S.I.], v. 27, p. 5-20, 2012.

HABERMAS, J. Direito e democracia: entre facticidade e validade. Rio de Janeiro: Tempo Brasileiro, 2011. v. II.

HABERMAS, J. Teoria do agir comunicativo: sobre a crítica da razão funcionalista. São Paulo: Martins Fontes, 2012. v. II.

IIZUKA, E. S.; GONÇALVES-DIAS, S. L. F; AGUERRE, P. Gestão social e cidadania deliberativa: a experiência de Ilha Comprida - São Paulo. Cadernos EBAPE.BR, [S.l.], v. 9, n. 3, p.748-779, 2011.

\section{INSTITUTO BRASILEIRO DE GOVERNANÇA}

CORPORATIVA (IBGC). [2014]. Acesso em: <http://www. ibgc.org.br/index.php>. Acesso em: 2 jul. 2014.
JUSTEN, C. E.; MORETTO NETO, L.; GARRIDO, P.

O. Para além da dupla consciência: gestão social e as antessalas epistemológicas. Cad. EBAPE.BR, [S.l.], v. 12, n. 2, p. 237-251, 2014.

KEINERT, T. M. M. Administração pública no Brasil: crises e mudanças de paradigmas. 2. ed. São Paulo: Annablume: FAPESP, 2007.

KETTL, D. F. The transformation of governance: public administration for twenty-first century. Baltimore, The Johns Jopkins Univerty Press, 2002.

KISSLER, L.; HEIDEMANN, F. G. Governança pública: novo modelo regulatório para as relações entre Estado, mercado e sociedade? Revista de Administração Pública, [S.I.], v. 40, n. 3, 2006.

MAIA, M. Gestão Social: reconhecendo e construindo referenciais. Textos \& Contextos, [S.l.], n. 4, p. 1-18, 2005.

MARSDEN, R.; TOWNLEY, B. Introdução: a coruja de Minerva: reflexões sobre a teoria na prática. In: CLEGG, S. R.; HARDY, C.; NORD, W. R. (Org.). Handbook de estudos organizacionais. São Paulo: Atlas, 2001. v. 2, p. 31-56.

MATIAS-PEREIRA, J. Governança no setor público. São Paulo: Atlas, 2010.

MATTIA, C.; ZAPPELLINI, M. B. Ética e coprodução de serviços públicos: uma fundamentação a partir de Habermas. Cadernos EBAPE.BR, [S.l.], v. 12, p. 573589, 2014.

MORRELL, K. Governance and the public good. Public Administration, [S.l.], v. 87, n. 3, p. 538-566, 2009.

OSBORNE, S. P. The New Public Governance? Public Management Review, [S.l.], v. 8, n. 3, p. 377-387, 2006.

PAES DE PAULA, A. P. Por uma nova gestão pública: limites e potencialidades da experiência contemporânea. Rio de Janeiro: FGV, 2005a.

PAES DE PAULA, A. P. Tréplica: comparação possível.

Revista de Administração de Empresas, [S.l.], v. 45, n. 1, p. 51-52, $2005 b$. 
PAES DE PAULA, A. P. Por uma nova gestão pública: reinserindo o debate a partir das práticas possíveis. In: CUNHA, A. S.; MEDEIROS, B. A.; AQUINO, L. C. (Org.). Estado, Instituições e Democracia: República. Brasília, DF: IPEA, 2010.

PARDINI, D. J.; GONÇALVES, C. A.; CAMARGOS, L. M. M. A Água - Governança Pública de Recursos Hídricos: manifestações dos stakeholders em Minas Gerais. Reuna, [S.l.], v. 18, n. 4, p. 37-56, 2013.

PECI, A.; RODRIGUES, S.; PIERANTI, O. P. Governança e New Public Management: convergências e contradições no contexto brasileiro. Organizações \& Sociedade, [S.l.], v. 15, p. 39-55, 2008.

PERES JR. M. R.; PEREIRA, J. R.; OLIVEIRA, L. C. Gestão Social sob a lente estruturacionista. Revista de Administração Mackenzie, [S.l.] v. 14, n. 6, p. 18-49, 2013.

PERES JR., M. R.; PEREIRA, J. R. Abordagens Teóricas da Gestão Social: uma análise de citações exploratórias. Cadernos EBAPE.BR, [S.I.], v. 12, p. 221-236, 2014.

PIERRE, J.; PETERS, B. G. Governance, politics and the state. London: Macmillan, 2000.

PINHO, J. A. G. Gestão social: conceituando e discutindo os limites e possibilidades reais na sociedade brasileira. In: RIGO, A. S. et al. Gestão social e políticas públicas de desenvolvimento: ações, articulações e agenda. Recife: UNIVASF, 2010.

PINHO, J. A. G.; SACRAMENTO, A. R. S. Accountability: já podemos traduzi-la para o português? Revista de Administração Pública, [S.l.], v. 43, n. 6, p. 1.3431.368, 2009.

POLLITT, C. Is the emperor in his underwear? An analysis of the impacts of public management reform. Public

Management, [S.l.], v. 2, n. 2, p. 181-199, 2000.

RAMOS, A. G. A redução sociológica. 2. ed. Rio de Janeiro: Coleção Tempo Novo, 1965.

RAMOS, A. G. A teoria administrativa e a utilização inadequada de conceitos. Revista de Administração Pública, [S.l.], v. 7 n. 3, p. 5-17, 1973.
RAMOS, A. G. A nova ciência das organizações: uma reconceituação da Riqueza das Nações. Rio de Janeiro: Editora da FGV, 1981.

RAQUEL, I.; BELLEN, H. M. V. Contribuição à concepção da governança pública: uma análise a partir da visão dos especialistas. In: XXXVI ENCONTRO DA ANPAD. Rio de Janeiro, 2012. Anais... Rio de Janeiro: ANPAD, 2012.

RAUPP, F. M.; PINHO, J. A. G. Construindo a accountability em portais eletrônicos de câmaras municipais: um estudo de caso em Santa Catarina. Cadernos EBAPE.BR, [S.1.], v. 9, n. 1, p. 116-138, 2011.

RHODES, R. A. W. The New Governance: governing without government. Political Studies, [S.l.], v. 44, p. 652-667, 1996.

RHODES, R. A. W. Understanding governance. Buckingham: Open University Press, 1997.

RHODES, R. Understanding governance: Ten years on. Organization Studies, [S.l.], n. 28, p. 1.243-1.264, 2009.

RICO, E. M.; RAICHELIS, R. (Org.). Gestão Social: uma questão em debate. São Paulo: EDUC/IEE, 1999.

SANTOS, M. H. C. Governabilidade, governança e democracia: criação de capacidade governativa e relações executivo-legislativo no Brasil pós-constituinte. Dados, [S.l.], v. 40, n. 3, 1997.

SANTOS, M. J. A.; PINHEIRO, L. B.; QUEIROZ, I. S. Q. Governança na administração pública: concepções do modelo australiano de Edwards et al. (2012) vis-à-vis as contribuições teóricas. In: XXXVIII ENCONTRO DA ANPAD. Rio de Janeiro, 2014. Anais... Rio de Janeiro: ANPAD, 2014

SAUERBRONN, F. F. Revisitando abordagens em governança pública em busca de uma proposta para o estudo da dimensão público-privada no SUS. In: XXXVIII ENCONTRO DA ANPAD. Rio de Janeiro, 2014. Anais... Rio de Janeiro: ANPAD, 2014.

\section{SCOLFORO, R. F. Lei de acesso à informação} e governança pública no município de Lavras: fatores favoráveis e limitantes. 2013. 144 f. Dissertação (Mestrado em Administração Pública) - Universidade Federal de Lavras, Minas Gerais, 2013. 
SECCHI, L. Modelos organizacionais e reformas da administração pública. Revista de Administração Pública, [S.l.], v. 43, n. 2, p. 347-369, 2009.

SILVA, E. E.; LASMAR, F. C.; PEREIRA, J. R. Redes sociais e governança democrática: o caso de uma instituição federal de ensino superior de Minas Gerais Brasil. Redes, [S.l.], v. 18, p. 104-123, 2013.

SOUSA, Y. M. et al. Gestão social e governança urbana: o caso do Portal da Amazônia. Administração Pública e Gestão Social, [S.l.], v. 6, p. 27-34, 2014.

SOUZA, F. C.; SIQUEIRA, J. F. A convergência da nova administração pública para governança pública: uma análise dos artigos internacionais e nacionais publicados entre 2000 e 2006. In: $7^{\circ}$ CONGRESSO USP DE CONTROLADORIA E CONTABILIDADE, 2007, São

Paulo. Anais... São Paulo: USP, 2007.

SUBIRATS, J. Cidadania e espaço público: a perspectiva da gestão social. In: TENÓRIO, F. G. (Org.). Cidadania e desenvolvimento local. Rio de Janeiro: Unijuí, 2007. p. 623-627.

TENÓRIO, F. G. Gestão social: uma perspectiva conceitual. Revista de Administração Pública, [S.l.], v. 32, n. 5, p. 7-23, 1998.

TENÓRIO, F. G. (Re)visitando o conceito de gestão social. Desenvolvimento em Questão, [S.l.], v. 3, p. 101-124, 2005.

TENÓRIO, F. G. Tem razão a administração? Ensaios de teoria organizacional. 3. ed. Ijuí: Editora Unijuí, 2008.

TENÓRIO, F. G. et al. Critérios para a avaliação de processos decisórios participativos deliberativos na implementação de políticas públicas. In: ENCONTRO DE ADMINISTRAÇÃO PÚBLICA E GOVERNANÇA, 3., 2008, Salvador. Anais... Curitiba: ANPAD, 2008.

TENÓRIO, F. G. Gestão Social: uma réplica. In: RIGO, A. S. et al. gestão social e políticas públicas de desenvolvimento: ações, articulações e agenda. Recife: UNIVASF, 2010.

TENÓRIO, F. G. et al. Da redução sociológica à aplicação de critérios para a avaliação de processos decisórios participativos deliberativos em arranjos institucionais na esfera pública. In: ENCONTRO DE ESTUDOS
ORGANIZACIONAIS. SANTA CATARINA, 2010. Anais... Florianópolis: ANPAD, 2010.

TENÓRIO, F. G. Escopo teórico. In: TENÓRIO, F. G. (Org.). Cidadania e desenvolvimento local: critérios de análise. Rio de Janeiro: Editora FGV, 2012.

\section{TEODÓSIO, A. S. S. Parcerias tri-setoriais na esfera}

pública: perspectivas, impasses e armadilhas para a modernização da gestão social no Brasil. 2008. 266 f. Tese (Doutorado) - Escola de Administração de Empresas de São Paulo, Fundação Getúlio Vargas, Rio de Janeiro, 2008.

TORRES, M. D. F. Estado, democracia e administração pública no Brasil. Rio de Janeiro: FGV, 2004.

VILLELA, L. E.; PINTO, M. C. S. Governança e gestão social em redes empresariais: análise de três arranjos produtivos locais (APLs) de confecções no estado do Rio de Janeiro. Revista de Administração Pública, [S.l.], v. 43, n. 5, p. 1.067-1.089, 2009.

WILSON, W. The study of administration. Political Science Quarterly, [S.I.], v. 2, n. 2, p. 197-222, 1887. 